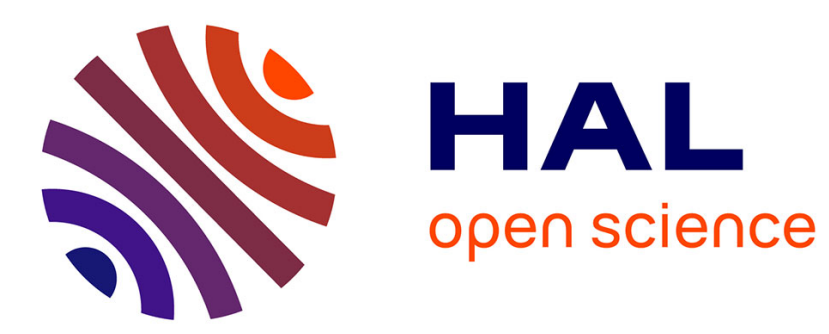

\title{
CHO-K1 host cells adapted to growth in glutamine free medium by FACS-assisted evolution
}

Juan Antonio Hernandez Bort, Beate Stern, Nicole Borth

\section{To cite this version:}

Juan Antonio Hernandez Bort, Beate Stern, Nicole Borth. CHO-K1 host cells adapted to growth in glutamine free medium by FACS-assisted evolution. Biotechnology Journal, 2010, 5 (10), pp.1090. 10.1002/biot.201000095 . hal-00583890

\section{HAL Id: hal-00583890 \\ https://hal.science/hal-00583890}

Submitted on 7 Apr 2011

HAL is a multi-disciplinary open access archive for the deposit and dissemination of scientific research documents, whether they are published or not. The documents may come from teaching and research institutions in France or abroad, or from public or private research centers.
L'archive ouverte pluridisciplinaire HAL, est destinée au dépôt et à la diffusion de documents scientifiques de niveau recherche, publiés ou non, émanant des établissements d'enseignement et de recherche français ou étrangers, des laboratoires publics ou privés. 


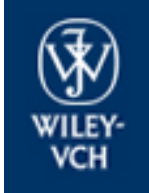

Biotechnology Journal

\section{CHO-K1 host cells adapted to growth in glutamine free medium by FACS-assisted evolution}

\begin{tabular}{|c|c|}
\hline Journal: & Biotechnology Journal \\
\hline Manuscript ID: & biot.201000095.R1 \\
\hline Wiley - Manuscript type: & Research Article \\
\hline $\begin{array}{r}\text { Date Submitted by the } \\
\text { Author: }\end{array}$ & $20-J u l-2010$ \\
\hline Complete List of Authors: & $\begin{array}{l}\text { Hernandez Bort, Juan Antonio; Universität Bodenkultur Vienna, } \\
\text { Biotechnology } \\
\text { Stern, Beate; Unitargeting Research AS } \\
\text { Borth, Nicole; Universität Bodenkultur, Biotechnology }\end{array}$ \\
\hline Primary Keywords: & Mammalian Biotechnology \\
\hline Secondary Keywords: & Metabolomics \\
\hline Keywords: & cell sorting, glutamine, host cell optimisation \\
\hline
\end{tabular}

\section{SCHOLARONE $^{\text {M }}$ \\ Manuscripts}




\title{
CHO-K1 host cells adapted to growth in glutamine free medium by FACS-assisted evolution
}

\author{
Juan A. Hernández Bort ${ }^{1}$, Beate Stern ${ }^{2}$ and Nicole Borth ${ }^{1}$ \\ ${ }^{1}$ Department of Biotechnology, University of Natural Resources and Applied Life Sciences, \\ Vienna, Austria \\ ${ }^{2}$ UniTargetingResearch AS, Bergen, Norway \\ Corresponding Author: Nicole Borth \\ University of Natural Resources and Applied Life Sciences \\ Department of Biotechnology \\ Muthgasse 18 \\ 1190 Vienna \\ Austria \\ Tel. +431476546232 \\ Fax: +4313697615 \\ Email: nicole.borth@boku.ac.at
}




\begin{abstract}
During the process of recombinant cell line optimisation for production of biopharmaceuticals, multiple cellular properties like robustness against stress, the attainment of high cell concentrations and maintenance of high viability must be considered in order to maximize protein yield. To improve growth and viability, glutamine is supplemented as an alternative energy source for rapidly dividing cells that oxidize glucose inefficiently. However, the resulting by-product ammonia is toxic at high concentrations and has a negative impact on protein glycosylation, a major quality determining parameter of biopharmaceuticals. In this work, the CHO-K1 cell line was adapted to a chemically defined medium and suspension growth within 3 weeks. Subsequently, the glutamine concentration was stepwise reduced from $8 \mathrm{mM}$ to $4 \mathrm{mM}$ and $2 \mathrm{mM}$. After each reduction, both the final cell concentration in batch and the viability decreased. In order to force a rapid evolution of cells to achieve high final cell concentrations, cells were seeded at high densities $\left(10^{7}\right.$ cells $\left./ \mathrm{ml}\right)$ and surviving cells were sorted by FACS or MACS when viability declined to $10 \%$ (typically after $24 \mathrm{~h}$ ). Sorted cells were grown in batch until viability declined to $10 \%$ and viable cells recovered again. The final sorted population was able to reach comparable or even better viable cell concentrations and showed a significantly improved viability compared to their ancestors. The $2 \mathrm{mM}$ glutamine-adapted cell line was directly transferred into glutamine-free medium and was able to grow at comparable rates without requiring further adaptation. Cells compensated the lack of glutamine by increasing their consumption of glutamate and aspartate.
\end{abstract}

\title{
KEYWORDS
}

glutamine; ammonia; CHO-K1 cells; cell sorting; assisted evolution; glutamine-free medium 


\section{INTRODUCTION}

Mammalian cells, and especially Chinese hamster ovary (CHO) cells, are widely used in biomedical research and the pharmaceutical industry for production of recombinant proteins. Thus, the improvement of cellular properties to increase productivity and product quality is of major interest.

During the last decades many studies were carried out in order to improve growth media. Glucose and glutamine concentrations are usually overdosed in mammalian cell culture media to achieve high growth rates and biomass concentration. However, such high concentrations lead to higher consumption rates of these components [1-3]. On the one hand, entry of glucose into the glycolytic pathway leads to pyruvate formation, which can either be shuttled into the tricarboxylic acid (TCA) cycle or converted into lactate. Due to the high flux of glucose to pyruvate and the inefficient coupling between glycolysis and TCA cycle, lactate accumulates during cultures, which has a negative impact in cells [3-5]. On the other hand, glutamine is the amino acid consumed with the highest rate and its importance for an optimal growth in cell culture has been known since the 50s [6]. Glutamine is an alternative energy source to glucose for rapidly dividing cells, as it is mostly metabolized via a truncated form of the TCA cycle [7]. Feeding of excess glutamine induces a high ammonium production in cell cultures $[1,8]$, which reduces viable cell density and productivity $[4,9-11]$ and alters glycoforms of proteins [12-15]. Moreover, it was also described that ammonia concentrations of $10 \mathrm{mM}$ will prevent growth of fibroblasts [16]. Although ammonia is derived mainly from deamidation of glutamine [6], the catabolism of the other amino acids present in the cultivation medium is also responsible for its overproduction [17]. When ammonium diffuses across the cell membrane, intracellular $\mathrm{pH}\left(\mathrm{pH}_{\mathrm{i}}\right)$ tends to decrease and electrochemical gradients are perturbed $[18,19]$. To overcome this problem, glutamine has been substituted by other less ammoniagenic carbon substrates like glutamate or asparagine 
$[20,21]$. In addition, sophisticated methods, including microporous hollow fiber modules or media filtration with cation exchangers, have been developed for waste product reduction in culture supernatants, in order to maximize the final product concentration and yield [22-24]. Substitution of glucose and glutamine by other energy substrates successfully reduced lactate and ammonia, respectively, but resulted in considerably decreased viable cell density [25]. However, it was also described that control of glutamine at low levels can improve cell densities [26].

For several years now, growth media for $\mathrm{CHO}$ cells have been optimised to a degree that allows growth in protein-free media [27-31]. In addition, cells have even been subjected to "Bioreactor evolution" [32] to improve their process relevant properties. All in all, increases in volumetric productivity during the last 10 years were mainly achieved by increases in the integral viable cell density (IVCD), by optimising process design and feeding strategies [3335]. Additional improvements were obtained by prolonging cell survival at the end of the culture by decreasing cell sensitivity to apoptotic stimuli. This strategy was tried by expression of anti-apoptotic genes in monoclonal antibody producing $\mathrm{CHO}$ cells [36-39].

In an attempt to obtain an optimised host cell line to be used for recombinant biologic production, we explored the possibility to achieve comparable growth and viability in a cell line independent of glutamine in the culture medium. In the present report we present a new approach to easily and rapidly evolve cells towards improved growth properties using cell sorting assisted evolution. Cells surviving a progressive stress treatment were sorted out of the parent population based on their cellular state and viability and typically showed enhanced robustness, a prolonged life span and higher viable cell density with concomitant improvement in IVCD. 


\section{MATERIALS AND METHODS}

\section{Cell line and media}

The original $\mathrm{CHO}-\mathrm{K} 1$ adherent cell line obtained from the American Type Culture Collection (ATCC) was adapted within three weeks to growth in suspension in CD CHO, a chemically defined, serum-free medium (Gibco, Invitrogen, Carlsbad, CA, USA) and supplemented with 8mM L-glutamine. Studies were carried out in spinner flasks with a working volume of $100 \mathrm{ml}$ at $37^{\circ} \mathrm{C}$ in a humidified atmosphere containing $7 \%$ carbon dioxide and with constant stirring at 50rpm.

\section{Progressive reduction of glutamine and Assisted Evolution}

Cells were seeded in a concentration of $10^{7}$ cells $/ \mathrm{ml}$ incubated at $37^{\circ} \mathrm{C}$ and surviving cells were sorted out with either Fluorescence Activated Cell Sorting (FACS) or Magnetic Activated Cell Separation (MACS) when viability declined to $10 \%$ after 20-24 hours. Surviving cells were expanded and seeded into a spinner flask with a starting concentration of $1 \times 10^{5}$ cells $/ \mathrm{ml}$. The batch was monitored until viability dropped below $10 \%$. Surviving cells were sorted out again and transferred into medium with reduced glutamine concentration. This procedure (Fig. 1) was repeated reducing glutamine supplement into culture medium after each completed cycle from $8 \mathrm{mM}$ to $4 \mathrm{mM}$, and from $4 \mathrm{mM}$ to $2 \mathrm{mM}$. Finally, cells adapted to $2 \mathrm{mM}$ glutamine were transferred into culture medium without glutamine supplementation.

\section{Viability and cell concentration}

Cell viability was estimated with a Neubauer hemocytometer using the trypan blue exclusion method. Total cell number was determined by counting cell nuclei with a Multisizer ${ }^{\mathrm{TM}} 3$ 
Coulter Counter (Beckman Coulter, Fullerton, CA, USA) after lysis of the cell membrane by incubation of samples for two hours in $0.1 \mathrm{M}$ citric acid containing $2 \%$ Triton $\mathrm{X}-100$.

\section{Cell sorting}

Viable cells were sorted out from cell culture bulk using either a FACS Vantage ${ }^{\mathrm{TM}}$ (Becton Dickinson, Franklin Lakes, NJ, USA), equipped with a Sort Enhancement Module, or a Dead Cell Removal kit in combination with a MACS column (Miltenyi Ltd, Germany). MACS protocol was performed according to supplier instructions. For FACS, a combination of a SSC-H / FSC-H gate and a gate for cells that exclude DAPI (4,6-diamidino-2-phenylindole) was used. DAPI is taken up and stains DNA only of damaged or dead cells. The intact sorted cells were deposited into a 6-well plate containing $3 \mathrm{ml}$ growth medium pre-incubated at $37^{\circ} \mathrm{C}$. Both cell sorting systems were tested and found to give similar results, with the MACS protocol faster and easier to handle. The FACS protocol is more time consuming, but due to its multiparameter character allows a finer discrimination between healthy cells and cells, that although still with an integral membrane, are already compromised.

\section{Analysis of glucose, lactate and ammonia.}

Concentration of glucose and lactate in the cell culture supernatant were determined using a YSI 7100 MBS Bioanalytical System (YSI Life Sciences, USA). Ammonia was measured by photometer with an Ammonia Assay Kit (Megazyme, Ireland) according to supplier's instructions.

\section{Amino acid analysis}

A HPLC Agilent 1200 Serie System equipped with a fluorescence detector (Ex:340nm; Em:450nm) was used for amino acids determination of the cell culture supernatant harvested 
every 4 days, including day 0 . A volume of $30 \mu \mathrm{l}$ sample mixed with $20 \mu \mathrm{l}$ orthophthalaldehyde (Pierce), was injected on a reversed phase Hypersil ODS column $(3 \mu \mathrm{m}$ particle size, $4.0 \times 100 \mathrm{~mm}$ ) thermostated at $25^{\circ} \mathrm{C}$, with the following linear gradient of sodium acetate 50mM, pH 5.70 (solvent A) and acetonitrile (solvent B): the concentration of $6 \% \mathrm{~B}$ was kept constant for 2 min., then the concentration of B was increased linearly from 2 to 12 min. to $9 \% \mathrm{~B}$, from 12 to $18 \mathrm{~min}$. to $19 \% \mathrm{~B}$, from 18 to $26 \mathrm{~min}$. to $22 \% \mathrm{~B}$, from 26 to $38 \mathrm{~min}$ to $42 \% \mathrm{~B}$ and from 38 to $40 \mathrm{~min}$ to $100 \%$. Column equilibrium to original conditions was from 40 to $50 \mathrm{~min}$ to $6 \%$ B. A flow rate of $1.5 \mathrm{ml} / \mathrm{min}$. was used throughout. Peaks were identified by retention time and concentrations determined relative to 3-(2-thienyl)-DLalanine (Fluka), an internal standard added to each sample. Calibration range was from $1 \mathrm{mg} / \mathrm{l}$ to $25 \mathrm{mg} / \mathrm{l}$.

\section{Plasmid and transient transfection}

For transient transfection, $10^{7}$ cells were co-transfected with $5 \mathrm{pmol}$ each of two plasmids bearing a human IgG1 heavy chain and lambda light chain under the control of a cmvpromoter. For the calculation of molar plasmid concentrations, the molecular weight average of a nucleotide pair was assumed to be $660 \mathrm{pg} / \mathrm{pmol}$. Only cells with viability greater than 95 $\%$ were used for transfection. According to Amaxa AG protocol, cell pellet was resuspended in $100 \mu$ l pre-mixed Solution kit V + Supplement (both included in Amaxa kit V), mixed with plasmids, and immediately nucleofected with the Amaxa Nucleofector (programm H-14). Directly after the electroporation procedure, cells were transferred into a culture flask with growth medium pre-warmed to $37^{\circ} \mathrm{C}$ at a concentration of $2 \times 10^{5}$ cells $/ \mathrm{ml}$. Samples were harvested to determine viability and starting cell number. Final cell density and viability were determined 48 hours after transfection. The protocol was previously evaluated to yield transfection efficiencies better than 90 and to have a standard deviation of $+/-15 \%$ [40] 


\section{IgG heavy chain determination by ELISA}

Microtiter Nunc MaxiSorp were coated with goat-anti-human-IgG-gamma-chain-specific (\#I3382; Sigma) diluted $1: 1000$ in $0.1 \mathrm{M}$ sodium bicarbonate buffer $(\mathrm{pH}=9.6)$ at $4^{\circ} \mathrm{C}$ overnight. The plates were washed and then incubated with serial dilutions of a self-purified IgG standard and culture supernatant samples for 1 hour in a dilution buffer containing $1 \%$ BSA at room temperature. After a wash step, the bound IgG was incubated with horse radish peroxidase (HRP) conjugated with a goat-anti-human-IgG (\#62-8420, Zymed) diluted 1:1000 in dilution buffer for 1 hour. For the detection of the antigen-antibody reaction, $200 \mu 1$ of a $0.4 \mathrm{mg} / \mathrm{ml}$ o-phenyldiamine dihydrochlorid (OPD) solution was added as substrate after a wash step, and incubated for 5 minutes at room temperature. The OPD reaction was stopped with $50 \mu \mathrm{l}$ of $2 \mathrm{M} \mathrm{H}_{2} \mathrm{SO}_{4}$ and read at $492 \mathrm{~nm}$. Calculation was carried out using a 4 parameter calibration curve with a detection range from 0 to $200 \mathrm{ng} / \mathrm{ml}$ IgG. Deviation of standard, control and sample replicates was less than $15 \%$.

\section{RESULTS}

\section{Extension of culture life span}

The rationale for this work arose from the concept that cells submitted to an iterative but not drastic change of milieu conditions should be able to evolve towards a more efficient metabolism and better adaption to the new conditions. When glutamine supplement was reduced in $\mathrm{CHO}-\mathrm{K} 1$ culture medium without adaptation, both growth rate and viable cell density decreased by approximately $20 \%$ (data not shown). This reduction became even worse during further routine passage in medium with the reduced glutamine content for a period of at least 6 weeks. In order to quickly restore cellular growth properties, cells were 
subjected to an iterative process of selection for the best adapted cells in reduced-glutamine culture medium.

To achieve this, $\mathrm{CHO}-\mathrm{K} 1$ cells were seeded at high density $\left(10^{7}\right.$ cells $\left./ \mathrm{ml}\right)$ and incubated at $37^{\circ} \mathrm{C}$ until viability declined to $10 \%$. This typically occurred after $20-24 \mathrm{~h}$. Surviving cells were sorted out with FACS or MACS and expanded in a T flask. This was necessary to remove dead cells and debris, which at high concentrations is toxic and would have killed the few remaining viable cells. In the second part of this approach, a batch with the expanded cells was started by seeding cells at $1 \times 10^{5}$ cells/ml in a spinner flask. The batch was monitored until viability dropped below $10 \%$. Surviving cells were sorted out. The process was repeated, while reducing glutamine supplement after each completed cycle from $8 \mathrm{mM}$ to $4 \mathrm{mM}$, and from $4 \mathrm{mM}$ to $2 \mathrm{mM}$. Finally, cells adapted to $2 \mathrm{mM}$ glutamine were transferred into culture medium without glutamine supplementation and showed the same growth profile as cells supplemented with $2 \mathrm{mM}$ glutamine. Thus for the $0 \mathrm{mM}$ glutamine adapted cell line no additional cycle in assisted evolution was required. The different adapted cell lines were maintained in the medium with the respective glutamine concentration in routine culture (on total now for over one year, without loss of phenotypic properties, data not shown).

In order to compare changes in cellular properties, batch cultures with these newly established CHO-K1 cell lines were started with the respective L-glutamine concentrations $(8 \mathrm{mM}, 4 \mathrm{mM}, 2 \mathrm{mM}$ and $0 \mathrm{mM})$ in spinner flasks with a working volume of $100 \mathrm{ml}$ and an initial concentration of $1 \times 10^{5}$ cells $/ \mathrm{ml}$, incubated at $37^{\circ} \mathrm{C}$ and $7 \% \mathrm{CO}_{2}$ with constant stirring at 50rpm. Results presented are the mean of two independent replicate batch cultures.

The $2 \mathrm{mM}$ and $0 \mathrm{mM}$ adapted cell line was able to increase the life span by approximately $30 \%$ relative to the parental cells and to maintain a viability of greater than $95 \%$ for 10 days (Fig. 2). Moreover, the integral of viable cells was increased by $22 \%$ for the $2 \mathrm{mM}$ culture and by $13 \%$ for the $0 \mathrm{mM}$ culture (Fig. 3 ). 


\section{Cellular Metabolism}

To evaluate the changes in metabolism that occurred upon assisted evolution, the adapted cell lines were cultivated in batch cultures in duplicate and the nutrient consumption of amino acids and glucose, as well as production of lactate (Fig. 4) and ammonium was analysed. The cells adapted to $2 \mathrm{mM}$ and $0 \mathrm{mM}$ glutamine, although lacking an important energy source, did not increase their glucose uptake rate nor did they shift towards mmore efficient utilization of glucose, as the ratio of lactate produced per glucose consumed remained the same. Instead, these cells compensated for carbon and nitrogen source by increasing the consumption of glutamate, aspartate and to a lesser degree asparagine (Fig. 5). Aspartate is produced in the cultures grown at 8 and $4 \mathrm{mM}$, while it is consumed in those at 2 and $0 \mathrm{mM}$. Uptake of other amino acids was slightly lower, while the production rate of alanine and to a lesser degree glycine was lower in these cultures than in the cultures grown at 8 and $4 \mathrm{mM}$ glutamine. Except for glutamine, no amino acid was completely depleted at the end of batch cultures. The low alanine secretion and ammonium production (Fig. 6) in culture supernatant by cells adapted to reduced-glutamine media during growth phase agrees with the conclusions of some authors, who reported that excess of ammonium production may be the cause of high alanine excretion after activation of transamination pathways [5, 9, 41].

Final ammonia concentration in $\mathrm{CHO}-\mathrm{K} 12 \mathrm{mM}$ grown at $0 \mathrm{mM}$ glutamine was comparable to CHO-K1 8mM and CHO-K1 4mM (Fig. 6), in spite of the absence of glutamine in growth medium. On the other hand, a reduction in ammonia production was observed during the exponential phase of batches.

\section{Growth rate and integral viable cell density}




\section{Effects on transient expression of IgG}

Previous studies have shown that glutamine reduction in cell culture media reduced protein production [25]. CHO-K1 $8 \mathrm{mM}, 4 \mathrm{mM} 2 \mathrm{mM}$ and $0 \mathrm{mM}$ cells were transfected with a total of 10pmol plasmid encoding IgG heavy chain and light chain genes to verify if any immediate effect on the specific productivity could be observed. The IgG product secreted in culture supernatant was quantified by ELISA at day 2 after transfection. Specific productivity reached $48 \mathrm{~h}$ after transfection was comparable in all cases (Fig. 7), considering the standard deviation of the method, which was $+/-15 \%$.

\section{DISCUSSION}

Survival of the best adapted organism to a new environment is generally known as natural selection. In an attempt to transfer the Darwinian Theory to an optimisation procedure for CHO-K1 cells, a simple strategy to improve properties of CHO-K1 was developed. Cells were submitted to an iterative and progressive alteration of milieu conditions by bulk selection of best adapted cells. 
Previous studies have shown that after decreasing the glutamine concentration in growth media to $0 \mathrm{mM}$, cellular metabolism shifted toward glycolysis leading to a higher glucose consumption rate [42]. Because glutamine is an important source for cellular glutamate, its reduction could act as a rate-limiting step in the synthesis of gluthatione (GSH), a tripeptide consisting of glutamate, glycine, and cysteine, that serves to protect cells from oxidative stress $[43,44]$. However, the specific glucose uptake and lactate production rates in the cell lines adapted to lower glutamine concentrations were not significantly changed, nor was the ratio of lactate produced per glucose consumed. The only difference was that in the culture grown without glutamine the cells were able to consume glucose down to a concentration of less than 200mg/l (Fig. 4).

A comparison of ammonia production (Fig. 6) revealed an initially dose dependent reduction in ammonia production with decreasing glutamine concentrations during exponential growth. On day 8 and 12 the ammonia concentrations were however comparable due to increased uptake of other amino acids in the cells grown at reduced glutamine concentrations. This result contradicts the intention of reducing glutamine to improve the glycosylation properties of produced proteins at later stages of the production process. In previous work on reducing or replacing glutamine $[20,23]$ the actual ammonia concentration was never tested. Nevertheless, by weening the cells of glutamine, we have achieved an increase in the integral of viable cell days (IVCD) of $20 \%$, this in spite of the prolonged lag during in early batch culture. The IVCD is the main determining factor for total product yield and thus economic process output. The next step in determining the usefulness of this new host cell line, will be to repeat the process with a producer cell line and verify effects on total high level productivity as well as on product quality. 


\section{CONCLUSION}

We presented a new approach to easily and rapidly evolve cells towards improved growth properties using a combination of Assisted Evolution Approach and cell sorting. Cells surviving a progressive stress treatment were sorted out of the improved parent population and typically showed improved robustness, a prolonged life span and enhanced viable cell density. The whole procedure of adapting cells from $8 \mathrm{mM}$ glutamine containing medium to 0mM glutamine took less than 10 weeks.

\section{ACKNOWLEDGMENTS}

The authors are grateful to Dominik Jeschek and Gabriele Lhota for amino acid analysis with reverse-phase HPLC.

\section{REFERENCES}

[1] Butler, M., Spier, R. E., The effects of glutamine utilisation and ammonia production on the growth of BHK cells in microcarrier cultures. Journal of Biotechnology 1984, 1, 187-196.

[2] Miller, W., Blanch, H., Wilke, C., A kinetic analysis of hybridoma growth and metabolism in batch and continuous suspension culture: effect of nutrient concentration, dilution rate, and pH. Reprinted from Biotechnology and Bioengineering, Vol. 32, Pp 947965 (1988). Biotechnol Bioeng 2000, 67, 853-871. 
[3] Glacken, M., Fleischaker, R., Sinskey, A., Reduction of waste product excretion via nutrient control: Possible strategies for maximizing product and cell yields on serum in cultures of mammalian cells. Biotechnol Bioeng 1986, 28, 1376-1389.

[4] Hassell, T., Gleave, S., Butler, M., Growth inhibition in animal cell culture. The effect of lactate and ammonia. Appl Biochem Biotechnol 1991, 30, 29-41.

[5] Ozturk, S., Riley, M., Palsson, B., Effects of ammonia and lactate on hybridoma growth, metabolism, and antibody production. Biotechnol Bioeng 1992, 39, 418-431.

[6] EAGLE, H., Nutrition needs of mammalian cells in tissue culture. Science 1955, 122, $501-514$

[7] Aledo, J., Glutamine breakdown in rapidly dividing cells: waste or investment? Bioessays $2004,26,778-785$.

[8] Ljunggren, J., Häggström, L., Glutamine limited fed-batch culture reduces the overflow metabolism of amino acids in myeloma cells. Cytotechnology 1992, 8, 45-56.

[9] Hansen, H. A., Emborg, C., Influence of ammonium on growth, metabolism, and productivity of a continuous suspension Chinese hamster ovary cell culture. Biotechnology Progress 2002, 10, 121-124.

[10] Cruz, H., Freitas, C., Alves, P., Moreira, J., Carrondo, M., Effects of ammonia and lactate on growth, metabolism, and productivity of BHK cells. Enzyme Microb Technol 2000, $27,43-52$. 
[11] Gawlitzek, M., Papac, D., Sliwkowski, M., Ryll, T., Incorporation of $15 \mathrm{~N}$ from ammonium into the $\mathrm{N}$-linked oligosaccharides of an immunoadhesin glycoprotein expressed in Chinese hamster ovary cells. Glycobiology 1999, 9, 125-131.

[12] Andersen, D., Goochee, C., The effect of ammonia on the O-linked glycosylation of granulocyte colony-stimulating factor produced by chinese hamster ovary cells. Biotechnol Bioeng 1995, 47, 96-105.

[13] Borys, M., Linzer, D., Papoutsakis, E., Ammonia affects the glycosylation patterns of recombinant mouse placental lactogen-I by chinese hamster ovary cells in a pH-dependent manner. Biotechnol Bioeng 1994, 43, 505-514.

[14] Valley, U., Nimtz, M., Conradt, H., Wagner, R., Incorporation of ammonium into intracellular UDP-activated $\mathrm{N}$-acetylhexosamines and into carbohydrate structures in glycoproteins. Biotechnol Bioeng 1999, 64, 401-417.

[15] Grammatikos, S., Valley, U., Nimtz, M., Conradt, H., Wagner, R., Intracellular UDP-Nacetylhexosamine pool affects $\mathrm{N}$-glycan complexity: a mechanism of ammonium action on protein glycosylation. Biotechnol Prog, 14, 410-419.

[16] Visek, W., Kolodny, G., Gross, P., Ammonia effects in cultures of normal and transformed 3T3 cells. J Cell Physiol 1972, 80, 373-381.

[17] McLimans, W., Blumenson, L., Repasky, E., Ito, M., Ammonia loading in cell culture systems. Cell Biol Int Rep 1981, 5, 653-660. 
[18] Schneider, M., Marison, I. W., von Stockar, U., The importance of ammonia in mammalian cell culture. Journal of Biotechnology 1996, 46, 161-185.

[19] Martinelle, K., Häggström, L., Mechanisms of ammonia and ammonium ion toxicity in animal cells: transport across cell membranes. J Biotechnol 1993, 30, 339-350.

[20] Christie, A., Butler, M., The adaptation of BHK cells to a non-ammoniagenic glutamatebased culture medium. Biotechnol Bioeng 1999, 64, 298-309.

[21] Huang, H., Yi, X., Zhang, Y., Improvement of Vero cell growth in glutamate-based culture by supplementing ammoniagenic compounds. Process Biochemistry 2006, 41, 23862392.

[22] Capiaumont, J., Legrand, C., Carbonell, D., Dousset, B., et al., Methods for reducing the ammonia in hybridoma cell cultures. J Biotechnol 1995, 39, 49-58.

[23] Bibila, T., Robinson, D., In pursuit of the optimal fed-batch process for monoclonal antibody production. Biotechnol Prog, 11, 1-13.

[24] Chen, K., Liu, Q., Xie, L., Sharp, P., Wang, D., Engineering of a mammalian cell line for reduction of lactate formation and high monoclonal antibody production. Biotechnol Bioeng 2001, 72, 55-61.

[25] Altamirano, C., Paredes, C., Cairó, J., Gòdia, F., Improvement of CHO cell culture medium formulation: simultaneous substitution of glucose and glutamine. Biotechnol Prog, 16, 69-75. 
[26] Lee, Y., Yap, M., Hu, W., Wong, K., Low-glutamine fed-batch cultures of 293-HEK serum-free suspension cells for adenovirus production. Biotechnol Prog, 19, 501-509.

[27] Sinacore, M., Drapeau, D., Adamson, S., Adaptation of mammalian cells to growth in serum-free media. Mol Biotechnol 2000, 15, 249-257.

[28] Schneider, Y., Optimisation of hybridoma cell growth and monoclonal antibody secretion in a chemically defined, serum- and protein-free culture medium. J Immunol Methods 1989, 116, 65-77.

[29] Louis Cleveland, W., Wood, I., Erlanger, B. F., Routine large-scale production of monoclonal antibodies in a protein-free culture medium. Journal of Immunological Methods $1983,56,221-234$.

[30] Schröder, M., Matischak, K., Friedl, P., Serum- and protein-free media formulations for the Chinese hamster ovary cell line DUKXB11. Journal of Biotechnology 2004, 108, 279292.

[31] Keen, M. J., Rapson, N. T., Development of a serum-free culture medium for the large scale production of recombinant protein from a Chinese hamster ovary cell line. Cytotechnology 1995, 17, 153-163.

[32] Prentice, H., Ehrenfels, B., Sisk, W., Improving performance of mammalian cells in fedbatch processes through "bioreactor evolution". Biotechnol Prog, 23, 458-464. 
[33] Durocher, Y., Butler, M., Expression systems for therapeutic glycoprotein production. Current Opinion in Biotechnology 2009, 20, 700-707.

[34] Khattak, S. F., Xing, Z., Kenty, B., Koyrakh, I., Li, Z. J., Feed development for fedbatch CHO production process by semisteady state analysis. Biotechnology Progress 2009, 9999, NA.

[35] Xie, L., Wang, D. I. C., Integrated approaches to the design of media and feeding strategies for fed-batch cultures of animal cells. Trends in Biotechnology 1997, 15, 109-113.

[36] Figueroa, B. J., Ailor, E., Osborne, D., Hardwick, J., et al., Enhanced cell culture performance using inducible anti-apoptotic genes E1B-19K and Aven in the production of a monoclonal antibody with Chinese hamster ovary cells. Biotechnol Bioeng 2007, 97, 877892.

[37] Mastrangelo, A. J., Hardwick, J. M., Zou, S., Betenbaugh, M. J., Part II. Overexpression of bcl-2 family members enhances survival of mammalian cells in response to various culture insults. Biotechnology and Bioengineering 2000, 67, 555-564.

[38] Meents, H., Enenkel, B., Eppenberger, H., Werner, R., Fussenegger, M., Impact of coexpression and coamplification of sICAM and antiapoptosis determinants bcl-2/bcl-x(L) on productivity, cell survival, and mitochondria number in CHO-DG44 grown in suspension and serum-free media. Biotechnol Bioeng 2002, 80, 706-716. 
[39] Astley, K., Al-Rubeai, M., The role of Bcl-2 and its combined effect with p21CIP1 in adaptation of $\mathrm{CHO}$ cells to suspension and protein-free culture. Appl Microbiol Biotechnol 2008, 78, 391-399.

[40] Pichler J., Galosy S., Mott J.E., Borth N, 2010, Selection of CHO Host Cell Subclones with Increased Specific Antibody Production Rates by Repeated Cycles of Transient Transfection and Cell Sorting, Biotechn. Bioeng. [In Press]

[41] Bonarius, H. P. J., Houtman, J. H. M., Gooijer, C. D. d., Tramper, J., Schmid, G., Activity of glutamate dehydrogenase is increased in ammonia-stressed hybridoma cells. Biotechnology and Bioengineering 1998, 57, 447-453.

[42] Jeong, Y.-H., Wang, S. S., Role of glutamine in hybridoma cell culture: Effects on cell growth, antibody production, and cell metabolism. Enzyme and Microbial Technology 1995, $17,47-55$

[43] Matés, J. M., Pérez-Gómez, C., de Castro, I. N., Asenjo, M., Márquez, J., Glutamine and its relationship with intracellular redox status, oxidative stress and cell proliferation/death. The International Journal of Biochemistry \& Cell Biology 2002, 34, 439-458.

[44] Roth, E., Oehler, R., Manhart, N., Exner, R., et al., Regulative potential of glutamine-relation to glutathione metabolism. Nutrition 2002, 18, 217-221. 


\section{Figure 1}

Assisted Evolution Approach. Glutamine concentration in media was reduced only after each completed cycle.

\section{Figure 2}

Profiles of growth (A) and viability (B) of CHO-K1 adapted to different glutamine concentrations with an initial cell density of $1 \times 10^{5}$ cells $/ \mathrm{ml}$.

\section{Figure 3}

Cumulative integrated viable cell density during the 12-day-batches. $\mathrm{CHO}-\mathrm{K} 12-2$ and 2-0 cell lines increased IVCD after Assisted Evolution.

\section{Figure 4}

(A) CHO-K1 2-0 metabolised glucose slower than compared cells lines in spite of lack of glutamine in growth medium. (B) Lactate production correlated with glucose consumption.

\section{Figure 5}

Different consumption and production profiles of selected amino acids during performed batch cultures. (A) Glutamine, (B) Glutamate, (C) Aspartate, (D) Asparagine, (E) Alanine, and $(\mathrm{F})$ Phenylalanine.

\section{Figure 6}

Final ammonia concentration at the end of batch cultures was similar in all cell lines.

\section{Figure 7}

Specific production rate $\left(\mathrm{q}_{\mathrm{P}}\right)$ of different CHO-K1 cells adapted to $8 \mathrm{mM}, 4 \mathrm{mM}$ and $2 \mathrm{mM}$ glutamine cultivated in different glutamine concentrations: $8 \mathrm{mM}, 4 \mathrm{mM}, 2 \mathrm{mM}$ and $0 \mathrm{mM}$. Cell concentration and IgG titers in the supernatant were determined at time $0 \mathrm{~h}$ and $48 \mathrm{~h}$ after transfection with 10pmol plasmid DNA. 


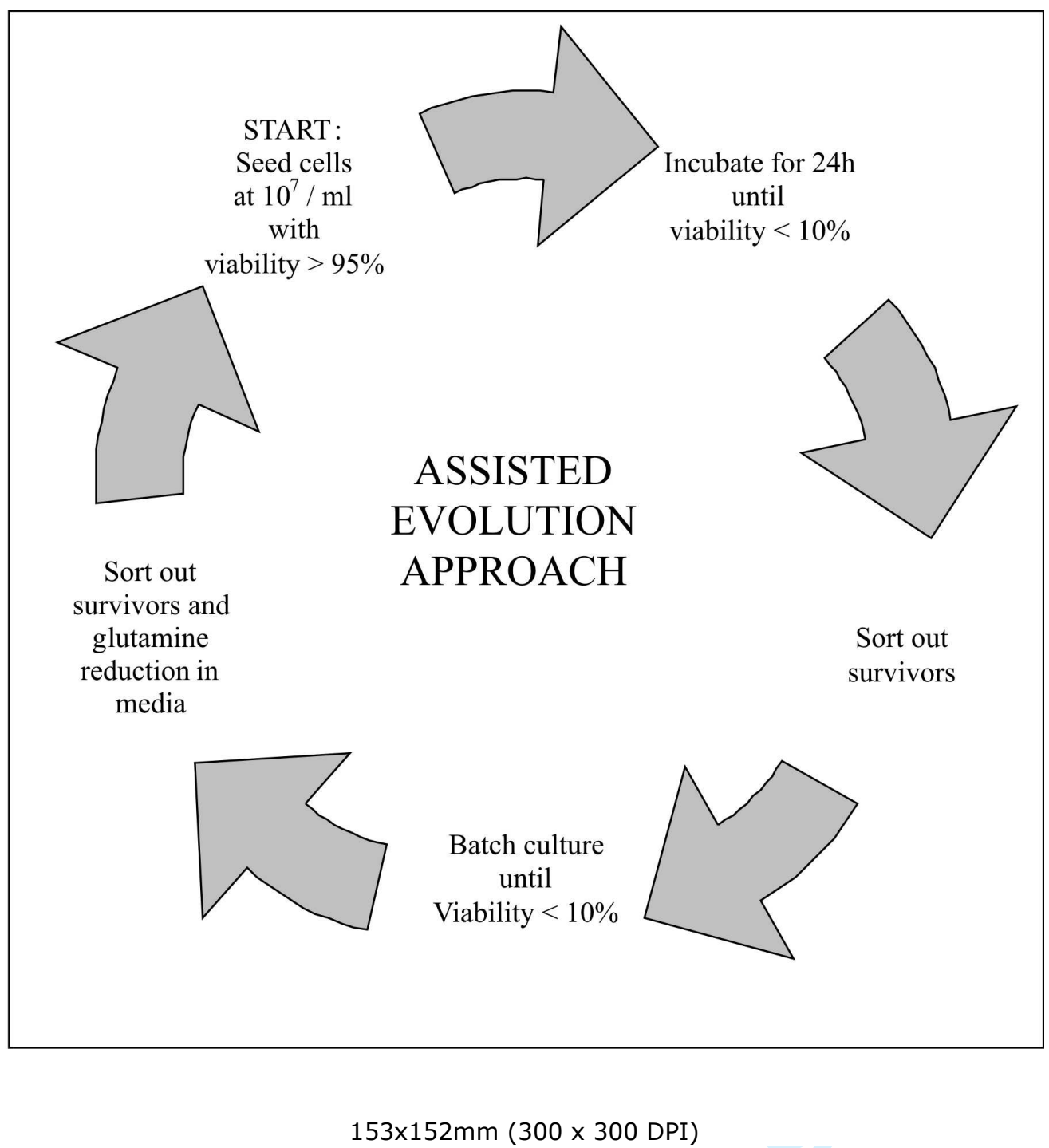

$153 \times 152 \mathrm{~mm}(300 \times 300$ DPI $)$ 

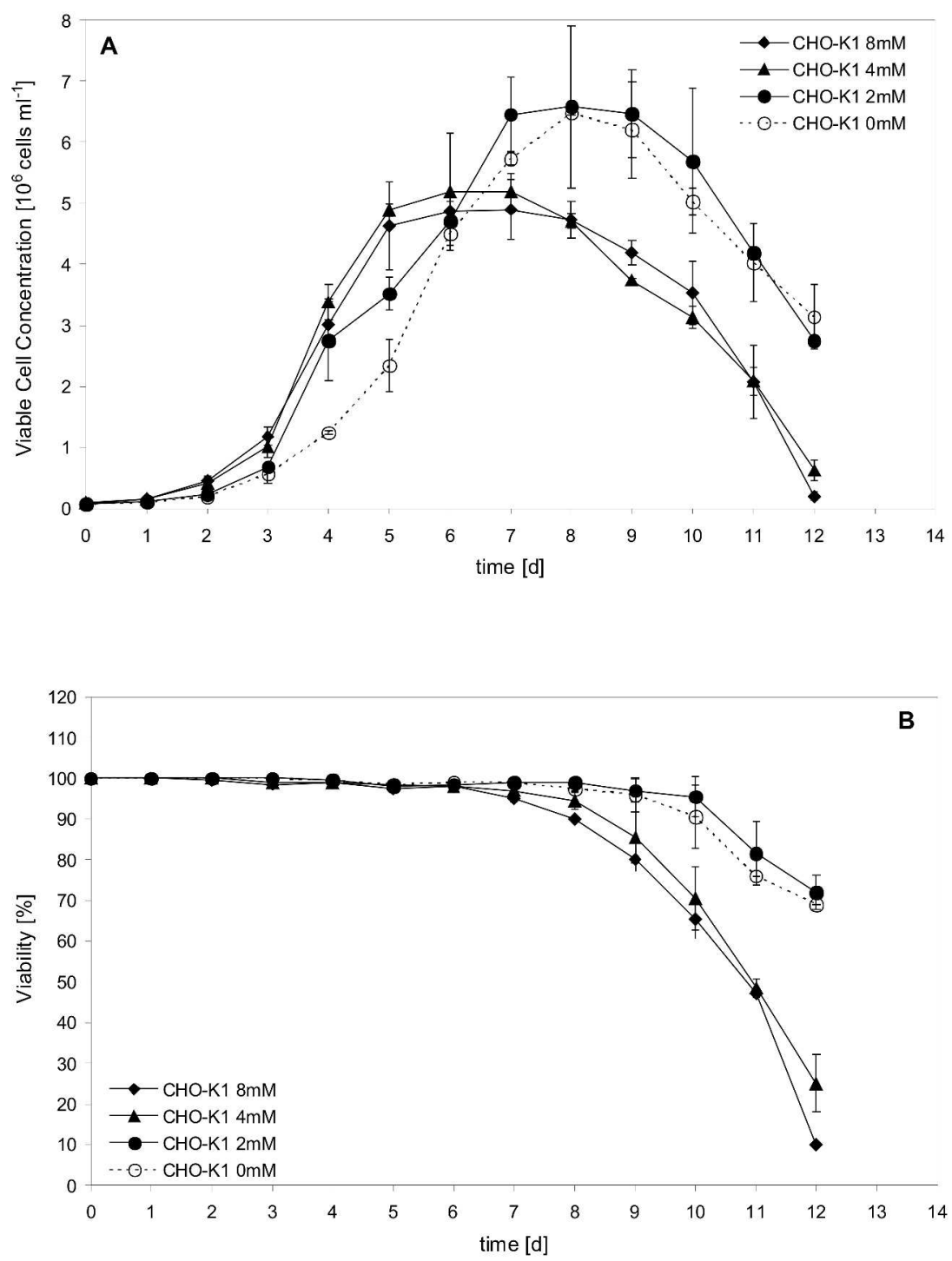

$257 \times 318 \mathrm{~mm}(300 \times 300$ DPI $)$ 


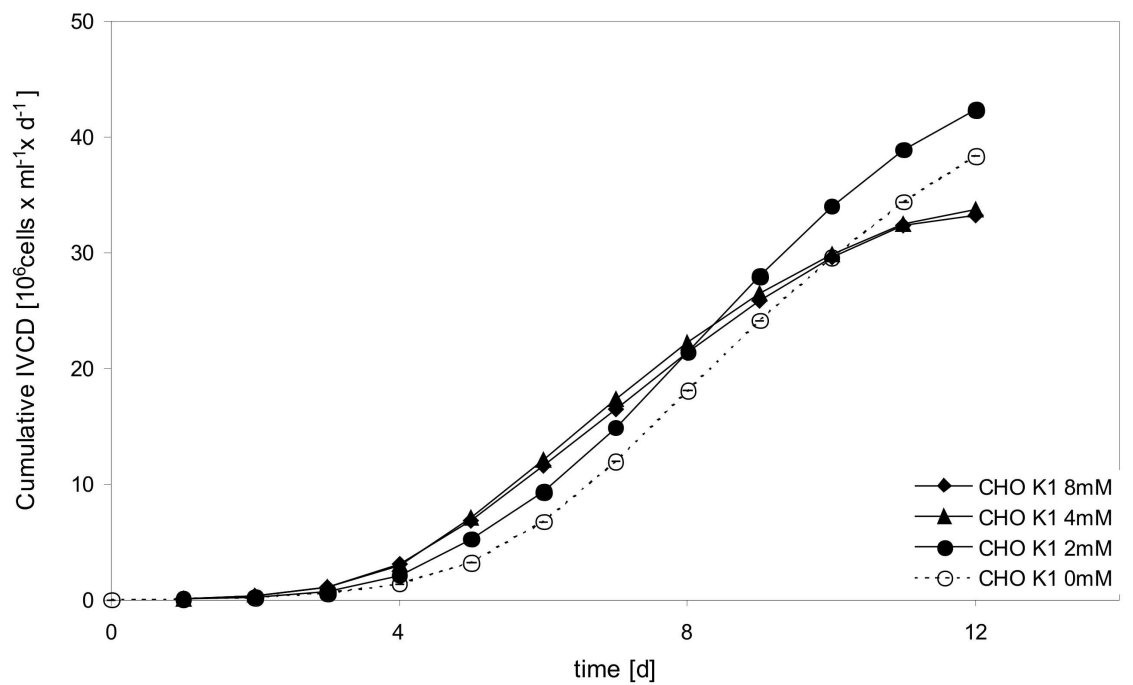

$256 \times 159 \mathrm{~mm}(300 \times 300 \mathrm{DPI})$ 

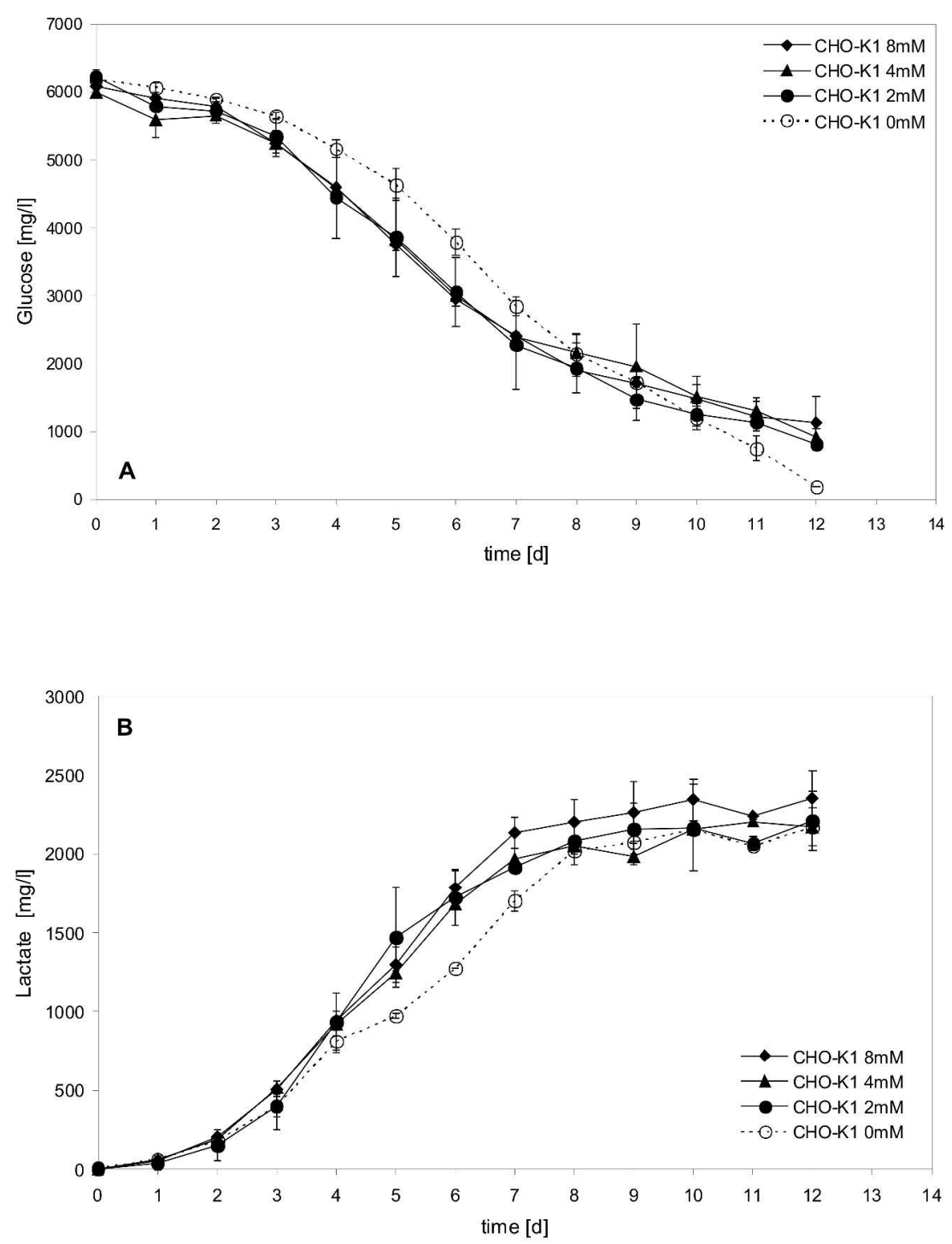

$257 \times 320 \mathrm{~mm}(300 \times 300$ DPI $)$ 


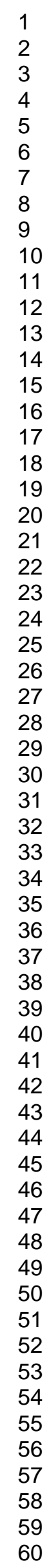
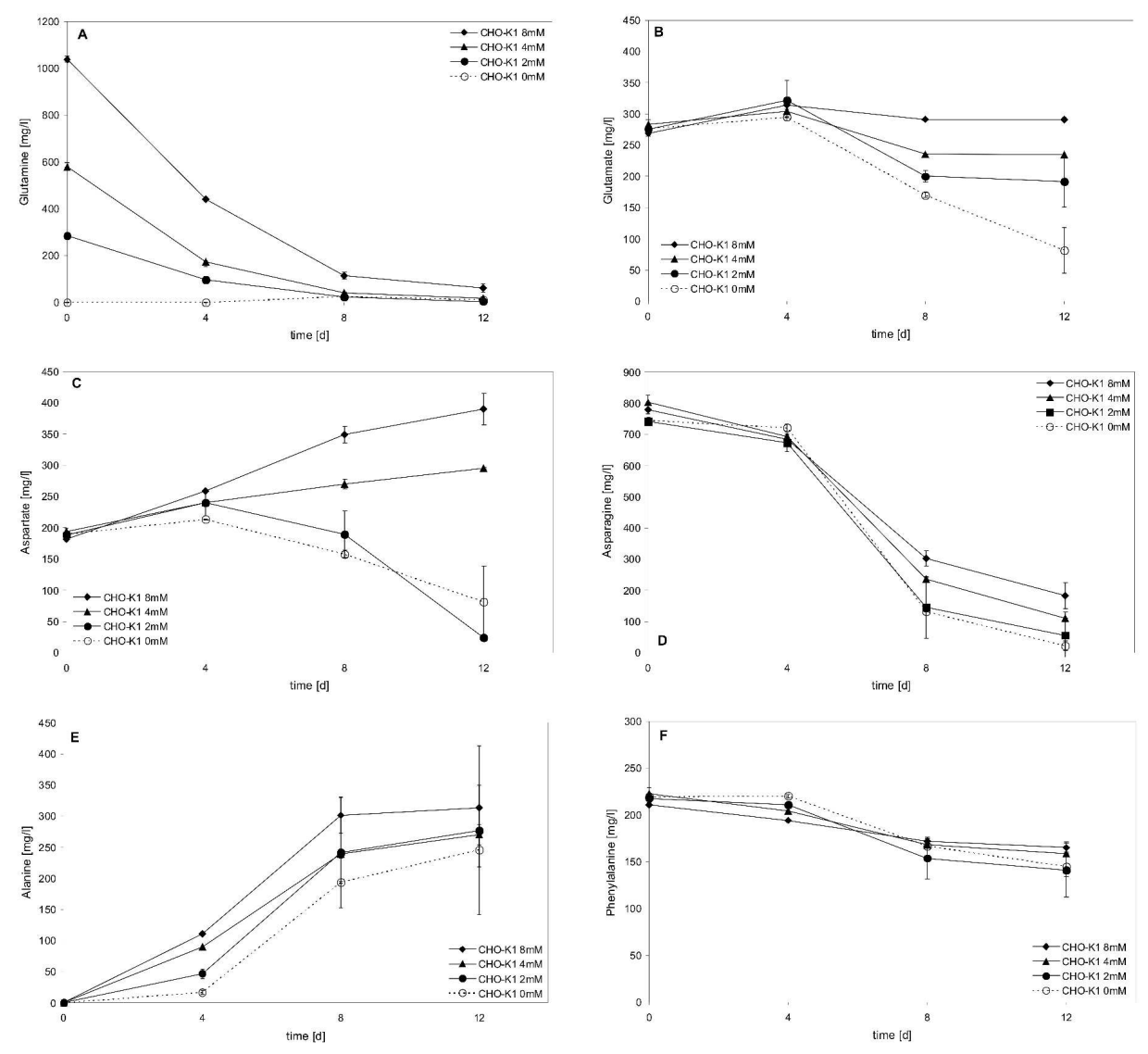

$500 \times 450 \mathrm{~mm}(300 \times 300$ DPI $)$ 


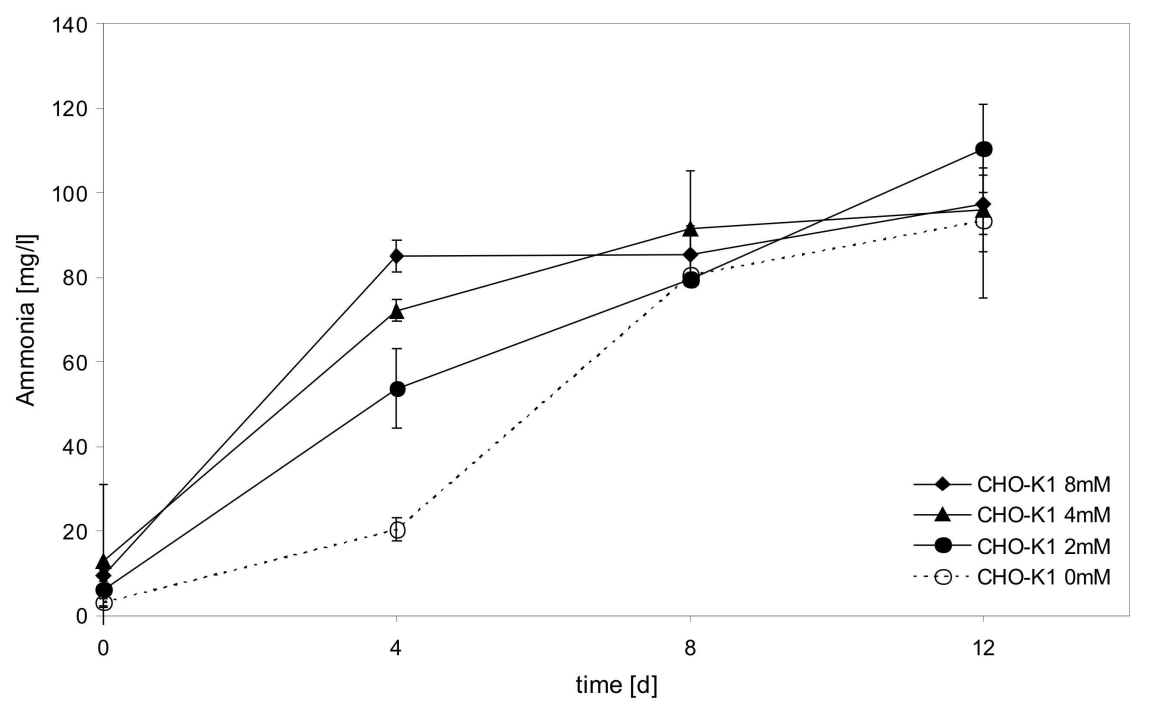

$256 \times 159 m m(300 \times 300$ DPI $)$ 


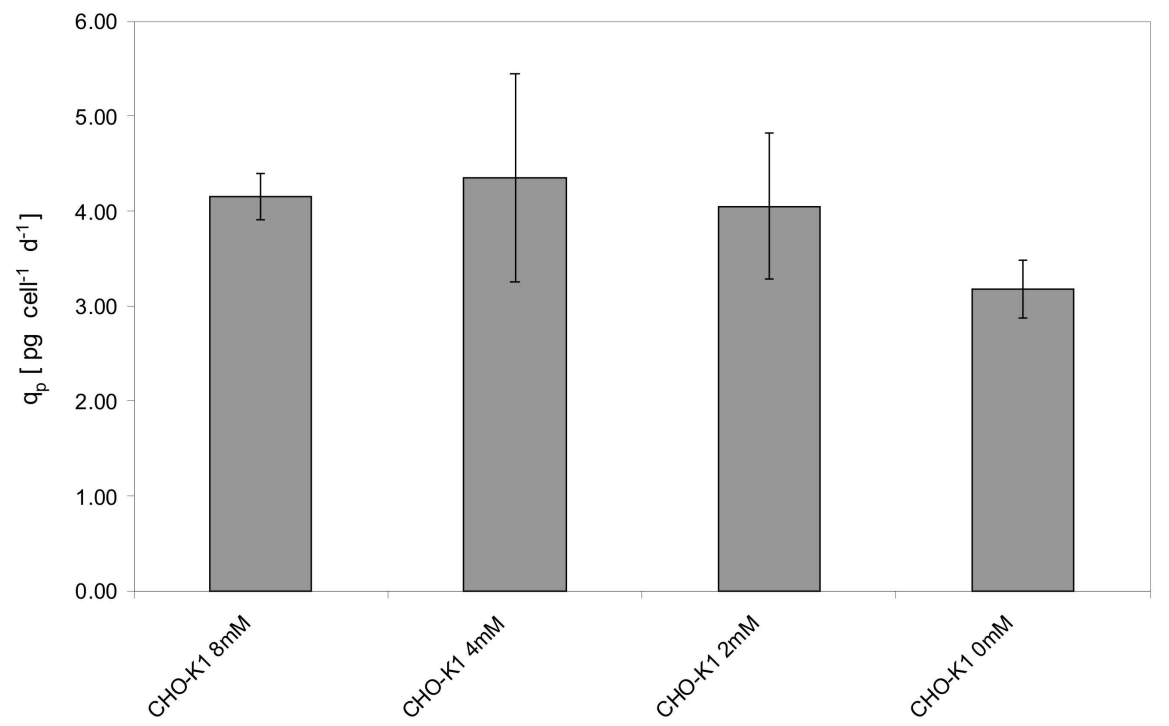

$256 \times 159 \mathrm{~mm}(300 \times 300 \mathrm{DPI})$ 